\title{
The Effect of CSR, Tunneling Incentive, Fiscal Loss Compensation, Debt Policy, Profitability, Firm Size to Tax Avoidance
}

\author{
Jihan Lestari ${ }^{\star 1}$ and Badingatus Solikhah ${ }^{2}$ \\ ${ }^{1,2}$ Accounting Department, Faculty of Economics, Universitas Negeri Semarang
}

\section{ARTICLE INFO}

\section{Article History:}

Received January 31, 2019

Accepted March 1, 2019

Available March 31, 2019

\section{Keywords:}

CSR; debt policy; firm size; fiscal loss compensation; profitability ; tax avoidance ; tunneling incentive

\begin{abstract}
The purpose of this research is to analyze the effect of variables of CSR, tunneling incentive, fiscal loss compensation, debt policy, profitability, and firm size on tax avoidance. The population of this research are 143Manufacturing Companies Listed on BEI In 2012-2016. This research used purposive sampling with a sample of 24 companies. The total sample unit is 120 samples. The analytical tool used in this research is multiple linear regressions. The collected data then analyzed with classic assumption test the hypothesis test by means of SPSS 21 . The result of this research is tunneling incentive, fiscal loss policy, and profitability have positive and significant effect to tax avoidance. Debt policies have a negative and significant effect on tax avoidance. Meanwhile, CSR and firm size does not affect tax avoidance. Based on the results of the study it can be concluded that only tunneling incentive, fiscal loss compensation, and profitability are able to increase tax avoidance.
\end{abstract}

(C) 2019 Published by UNNES. This is an open access article under the CC BY license (http://creativecommons.org/licenses/by/4.0/)

\section{INTRODUCTION}

Tax is one of the state revenues that contribute the most in supporting national development and financing. This is evidenced by the realization of the Revised State Budget in 2016which shows that the tax sector revenues reached $\mathrm{Rp}$. 1,283.6 trillion or contributed $83.4 \%$ of the total state revenues of Rp. 1,551.8 trillion, (source: $\underline{w w w}$. kemenkeu.go.id, 2017). In various countries, tax revenues are very important to be used for national development activities and sources of funds for public welfare. Therefore, tax has always been the main focus of the government because it has become the largest source in the Revised Budget State (APBN-P) (Siswanti \& Kiswanto, 2013).

Turyatini (2017) stated that the development of tax revenue quantity is not accompanied by an increase in the growth of tax revenues and the achievement of the target of state tax revenues. On the one hand, the government is trying to improve the optimization of tax revenues. On the other hand, the company considers taxes as a burden because taxes can reduce profits so that the company wants minimum tax payments (Setyaningrum \& Suryarini, 2016).

\footnotetext{
*E-mail: jihanlestari11@gmail.com

Address: L2 Building 2nd floor, Campus Sekaran, Gunungpati, Semarang, Indonesia, 50229
}

From a business perspective, business people generally identify tax payments as a burden that will reduce after-tax profit, rate of return, and cash flow (Suandy, 2006). If viewed from the other side, the main goal of a company is to get maximum profit to achieve the welfare of the company's stakeholders, so that this is the basis of the company in carrying out tax avoidance actions (Putri \& Suryarini, 2017). Based on the agency theory, conflict of interest between the government and taxpayers, this is commonly called conflict of interest, which triggers a problem, namely the practice of tax avoidance carried out by taxpayers in order to minimize their tax burden.

Data obtained from the Directorate General of Budget (2017) states that the realization of tax revenues

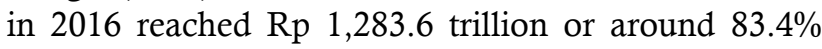
of the 2016 State Budget target of $\mathrm{Rp} 1,539.17$ trillion (source:www.kemenkeu.go.id). The amount of realization that is smaller than this target can indicate that it turns out that state revenue from the tax sector has not been optimal and raises the suspicion that the company has been behaving to avoid taxes (tax avoidance). Another indication that the company conducts tax avoidance is that in 2016 the government has issued a program of tax amnesty policy in which the Directorate General of Taxes stated that state revenue from the tax amnesty program in the form of ransom from non-MSMEs of Rp14.6 trillion. The revenue from non-MSME corpo- 
rate taxpayers, which reached IDR 14.6 trillion, shows that in fact the company has carried out tax avoidance with a very large amount of around $\mathrm{Rp} 14.6$ trillion.

Research conducted by Lanis \& Richardson (2011), Jones, et.al., (2017) and Zhang et.al. (2013) stated that there is a negative relationship between CSR and tax avoidance. Whereas in research of Wahyudi (2015) stated that there is no significant influence between CSR and tax avoidance. Darmawan \& Sukartha (2014) examined profitability has a positive effect on tax avoidance. Kurniasih \& Sari (2013) and Mulyani \& Suryarini (2017) stated that profitability has a negative effect on tax avoidance. Siregar \& Widyawati (2016) stated that profitability does not affect on tax avoidance. Halioui, Neifar, \& Abdelaziz (2016), Kurniasih \& Sari (2013) stated firm size has a positive effect on tax avoidance. Hsieh (2012) stated that firm size has a negative effect on tax avoidance. Whereas Mulyani and Suryarini (2017) stated that firm size does not affect on tax avoidance. The purpose of this study is to analyze the effect of CSR, tunneling incentive, compensation for fiscal losses, debt policy, profitability, and firm size on tax avoidance.

The originality of this research is the novelty of the research variable. This study adds a tunneling incentive variable as the independent variable that influences tax avoidance. This is because the study of the effect of tunneling incentive toward tax avoidance has not been investigated in Indonesia. Therefore, it is feasible to be used as a novelty of the research. The next difference lies in the proxy measurement of CSR. In the previous studies, CSR was measured using the CSR Disclosure Index proxy, while in this research it is measured using the Opportunity Cost Approach (OCA) method adopted from the study of Andreas, et. al. (2015), so that it is expected to be able to add to the literature in CSR variables. Previous studies mostly only made observations between 2 (two) to 3 (three) years only, with observations of 5 (five) years expected to better illustrate the effect of tax avoidances accurately.

Agency theory explains the relationship between company management (agents) and shareholders (principals) (Jensen \& Meckling, 1976). Scott (2012) stated that agency problems arise because of differences in interests between shareholders and managers. Shareholders as providers of capital want to get the maximum benefit for the results of their investment, while management that is authorized to manage the company is assumed to want to get high financial compensation from the company. The existence of agency theory spurs agents to increase corporate profits. When the profit earned increases, the amount of income tax will increase in accordance with the increase in corporate profits. Darmawan \& Sukartha (2014) stated that agents in agency theory will try to manage their tax burden so as not to reduce agent performance compensation as a result of reduced corporate profits by the tax burden. Performance measurement indicators can be observed from optimal profits, for this reason an effort to reduce the tax burden as low as possible done in a way that is classified as legal, namely tax avoidance (Mulyani \& Suryarini, 2017).

CSR disclosure aims to gain positive legitimacy from the community. Social responsibility activities are generally realized by companies in the form of CSR which include aspects of profit, humanity (people) and environment (planet) and compliance with taxes. Paying taxes is a form of CSR activity indirectly to the community because basically taxes are used to support national development and improve people's welfare. If the company that carries out CSR activities but acts to avoid taxes, the company will lose its reputation in the eyes of its stakeholders and will eliminate the positive impact associated with CSR activities that have been carried out.

Legitimacy theory explains that the management system of a company is oriented towards alignments with society, individual governments and community groups (Siswanti \& Kiswanto, 2013). The concept of legitimacy shows that there is a corporate responsibility towards society that requires companies to act ethically in accordance with the norms and value systems where they operate. Thus, companies that carry out CSR will tend to not do tax avoidance because it is not an ethical and responsible action

This study supports Lanis \& Richardson (2015), Kiesewetter \& Manthey (2017), and Siswianti \& Kiswanto (2016). The result shows that CSR has a negative effect on tax avoidance. This result means that the more disclosure of CSR disclosed by the company, the lower the level of tax avoidance by the company.

\section{$H_{1}$ : CSR has a negative effect on tax avoidance}

Tunneling incentive is the behaviour of management or majority shareholders to transfer corporate assets and profits to their own interests under any name or form (Jewel, 2012). One of the forms of tunneling incentive is transfer pricing. Lo, et al. (2010) stated that many companies use transfer pricing as a strategy to reduce their tax obligations. In addition, by making a sale at a price below the market price it will make the company seem to lose by maximizing the burden and ultimately resulting in reduced income. This can ultimately reduce the tax burden that should be imposed and reduce import duties.

Agency theory considers that the management of the company as an agent will take advantage of the existence of tax incentives in the form of tunneling incentive. Tunneling incentives can reduce the tax burden and increase post-tax profit in that year. This study supports previous research that belongs Tang (2016). The results say that tunneling can be one of the tax avoidance incentives.

\section{$H_{2}$ : Tunneling Incentive has a positive effect on tax avoidance}

Companies that suffer fiscal losses in a period, the company will be given relief by the government to pay taxes, commonly referred to as fiscal loss compensation. This matter has been regulated in Law Number 36 of 2008 which states that fiscal losses can be compensated for the next five years in a row after the company experiences such losses. Therefore, for five consecutive years the tax burden paid by the company will be less. 
According to agency theory, the management of the company as an agent will take advantage of the existence of tax incentives in the form of compensation from fiscal losses in the previous year. With the existence of such compensation, it will definitely reduce the tax burden and profit after tax in that year will be higher. This research is in line with research conducted by Kurniasih and Sari (2013) proves that compensation for fiscal losses has a significant positive effect on tax avoidance.

\section{$\mathrm{H}_{3}$ : Fiscal Loss Compensation has a positive effect on tax avoidance}

The optimal level of debt is achieved when tax savings reach the maximum amount. Agency theory has implications for a company, namely: the existence of interest costs on debt will reduce corporate tax costs, so that in this case the manager would prefer to use debt to fund their company in order to benefit from the interest costs on debt to reduce the company's tax burden. The decrease in corporate tax burden will result in increased corporate profits, with increasing profits, it can be said that the company's performance also increases, and in such circumstances managers will benefit in the form of increased compensation received.

The trade off theory states that the use of debt by companies can provide benefits obtained by tax shields (Mutamimah \& Rita, 2009). Law of the Republic of Indonesia No. 36, 2008 states that loan interest is a fee that can be deducted from taxable income. The existence of a negative influence between debt policy on tax avoidance because the company has taken advantage of loopholes in Law Number 36 of 2008 by choosing debt funding to finance its operations in order to incur interest costs. (Mulyani \& Suryarini, 2017).

This research is in line with research of Noor et al. (2010) and Kurniasih \& Sari (2013). The results show that companies benefit from the costs of reducing interest taxes which further reduces their taxable income. This negative relationship occurs because companies that have high debt will get tax incentives in the form of deductions from loan interest so that the company does not need to take tax avoidance actions.

\section{$\mathrm{H}_{4}$ : Debt policy has a positive effect on tax avoidance}

Slamet (2006) explained that profitability describes the ability of a company to generate profits during a certain period at the level of sales, assets and own capital. Company profitability indicated by Return On Assets (ROA). ROA is an indicator that reflects the company's financial performance. The higher the ROA value, the greater the profit the company gets. High profits cause the amount of tax to be paid by the company also high.

Agency theory states that company management will do various ways so that the company's profitability ratio is high because with high profitability the agent will get high compensation from the principal. Companies with a high level of efficiency and high income tend to face a low tax burden because companies with high income succeed to take advantage of the benefits of tax incentives and other tax deductions (Darmadi \& $\mathrm{Zu}$ laikha, 2013). Research conducted by Kurniasih \& Sari (2013) shows that there is a positive influence between ROA on tax avoidance.

\section{$\mathrm{H}_{5}$ : Profitability has a negative effect on tax avoid- ance}

Large companies are more likely to use the resources they have than using financing originating from debt (Darmawan \& Sukartha, 2014). Siegfried (1972) stated that large companies have large resources to influence the political process as they wish including tax planning to achieve optimal tax savings. Companies that are included in large companies have greater resources than companies that have smaller scale to carry out tax management. Small-scale companies cannot be optimal in managing their tax burden due to lack of experts in taxation (Darmadi \& Zulaikha, 2013).

Political Power Theory explains that large companies have large resources to influence the political process that is desired and profitable for the company including tax avoidance in order to achieve optimal tax savings (Anouar, 2017; Mulyani \& Suryarini, 2017). This is because large companies have more and more complex corporate operating activities so that there are gaps to take advantage of tax avoidance decisions. In

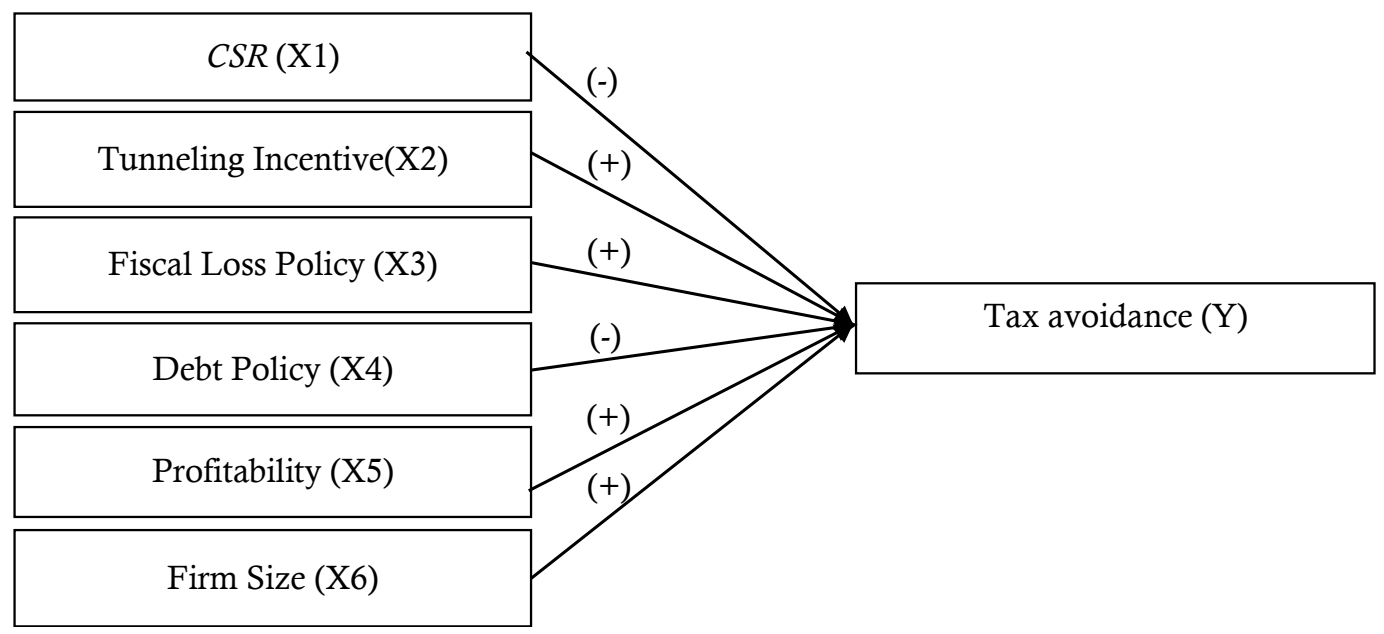

Figure 1. Theoretical Framework 
addition, large companies tend to have more space for good tax planning and adopt effective accounting practices to reduce the company's ETR (Rodriguez \& Arias, 2012). Darmawan \& Sukartha (2014) and Mulyani \& Suryarini (2017) states that the greater the resources a company has, the greater the opportunity to manage its tax burden.

\section{$\mathrm{H}_{6}$ : Firm size has a positive effect on tax avoidance}

Based on the description that has been described, the theoretical framework of this research can be seen in Figure 1.

\section{RESEARCH METHOD}

This research was a type of quantitative research. The population in this study were 143 manufacturing companies listed on the Indonesia Stock Exchange in 2016. Determination of research samples used purposive sampling method with sampling criteria described in the previous chapter. It is obtained the number of research samples to be tested which are detailed in Table 1.

The variables in this study are seven, namely one dependent variable and six independent variables. The dependent variable is tax avoidance. Independent variables are CSR, tunneling incentive, fiscal loss compensation, debt policy, profitability, and firm size. The operational definition of the dependent and independent variables can be seen in the Table 2 .

Data analysis methods used in this study included descriptive statistical analysis, classical assumption test, multiple linear regression analysis and hypothesis testing using SPSS 21.

Table 1. Research Population and Samples

\begin{tabular}{llc}
\hline No. & \multicolumn{1}{c}{ Explanation } & Number \\
\hline 1. & Manufacturing company listed on the & 143 \\
IDX & \\
2. & $\begin{array}{l}\text { Manufacturing companies that have } \\
\text { units of rupiah }\end{array}$ \\
3. $\begin{array}{l}\text { Companies issued annual reports and } \\
\text { financial reports in a complete period } \\
\text { of 2012-2016 as well as all data infor- } \\
\text { mation needed in the study. }\end{array}$ & \\
4anufacturing companies that do \\
$\begin{array}{l}\text { not experience losses during the study } \\
\text { period }\end{array}$
\end{tabular}

Source : Secondary data processed, 2018

Table 2. Operational Definition

\begin{tabular}{|c|c|c|}
\hline Variables & Definitions & Measurement \\
\hline Tax avoidance & $\begin{array}{l}\text { Tax avoidance is an activity utilizing } \\
\text { opportunities in tax rules to minimize tax } \\
\text { value. (Brian \& Martani, 2014) }\end{array}$ & $\begin{array}{l}E T R=\frac{\text { Income Tax Expense }}{\text { Income Before Tax }} \\
\text { Lanis \& Richardson (2011) }\end{array}$ \\
\hline CSR & $\begin{array}{l}\text { CSR is a belief about the actions considered right } \\
\text { that considers economic, social, environmental } \\
\text { issues and the impact of other externalities of } \\
\text { the corporate actions (Hoi, Wu, \& Zhang, 2013). }\end{array}$ & $\begin{array}{l}\operatorname{CSR}=\frac{\operatorname{CSR} \text { Cost }}{\text { Total Operational Cost }} \\
\text { Andreas, et. al. (2015) }\end{array}$ \\
\hline Tunneling Incentive & $\begin{array}{l}\text { Tunneling Incentive is management or majority } \\
\text { shareholders behaviour who transfer company } \\
\text { assets and profits for their own purposes under } \\
\text { any name or form (Jewel, 2012). }\end{array}$ & $\begin{array}{l}\text { With a dummy variable, score } 1 \text { if it } \\
\text { includes foreign capital of } 25 \% \text {, and } \\
\text { score } 0 \text { if it is below } 25 \% \\
\text { Yuniasih, (2012) }\end{array}$ \\
\hline $\begin{array}{l}\text { Fiscal Loss } \\
\text { Compensation }\end{array}$ & $\begin{array}{l}\text { Fiscal loss compensation is a corporate fiscal } \\
\text { loss that can be compensated and is only allowed } \\
\text { for the next five years in a row. (Kurniasih \& } \\
\text { Sari, 2013) }\end{array}$ & $\begin{array}{l}\text { Dummy variable, score } 1 \text { if there is } \\
\text { compensation for fiscal loss, and score } \\
0 \text { if there is no compensation at the } \\
\text { beginning of the year. } \\
\text { Kurniasih \& Sari (2013) }\end{array}$ \\
\hline \multirow[t]{2}{*}{ Debt Policy } & $\begin{array}{l}\text { Debt policy is a policy taken by companies to } \\
\text { finance through debt (Kurniasih \& Sari, 2013). }\end{array}$ & $D E R=\frac{\text { Total Liabilities }}{\text { Total Equities }}$ \\
\hline & & Kurniasih \& Sari (2013) \\
\hline Profitability & $\begin{array}{l}\text { Profitability is the ability of a company to } \\
\text { generate profits for a certain period at a certain } \\
\text { level of sales, assets and capital (Slamet, 2006). }\end{array}$ & $\begin{array}{l}\text { ROA }=\frac{\text { Profit After Tax }}{\text { Total Asset }} \\
\text { Noor et al. (2010) }\end{array}$ \\
\hline Firm Size & $\begin{array}{l}\text { Firm size is a scale that determines the size of } \\
\text { the company that can be seen from the equity } \\
\text { value, sales value, total employee's total assets } \\
\text { (Ngadiman \& Puspitasari, 2014). }\end{array}$ & $\begin{array}{l}\text { Size }=\text { Ln (Total Sales) } \\
\text { Noor et al. (2010) }\end{array}$ \\
\hline
\end{tabular}




\section{RESULTS AND DISCUSSIONS}

The coefficient of determination $\left(\mathrm{R}^{2}\right)$ essentially measures how far the model's ability in explaining the variation of the dependent variable. The result of coefficient of determination test $\left(\mathrm{R}^{2}\right)$ obtained the value of Adjusted R Square of 0.284 or $28.4 \%$. This means $28.4 \%$ of tax avoidance variable can be explained by the six independent variables while $71.6 \%$ is explained by other variables outside the model.

The $t$ statistical test basically shows how far the influence of one explanatory/ independent variable individually in explaining the variation of the dependent variable (Ghozali, 2013:98). The t statistical test analysis produces the following statistical Equation 1.

$\mathrm{TA}=-0.407-2.004 \mathrm{CSR}+0.038 \mathrm{TUN}+0.044 \mathrm{KRF}$ $-0.022 \mathrm{DER}+0.303 \mathrm{ROA}+0.004$ SIZE.

\section{The Effect of Corporate Social Responsibility on Tax avoidance}

Based on the results of statistical test which has been conducted in Table 3, it shows that CSR does not affect on tax avoidance. Thus, the first hypothesis of this study is rejected. The size of CSR is not able to influence the company in conducting tax avoidance. The result of this study is in line with the research of Rini, et al., (2015), Winarsih et al. (2014), and Wahyudi (2015). The result of this study does not support the legitimacy theory. The cause of this unexpected result is due to practice of CSR in Indonesia which is still low, so that its significance for tax avoidance has no effect at all (Wahyudi, 2015).

Winarsih, et al. (2014) stated that CSR information disclosed in the report is not necessarily in accordance with the actual conditions, so that the amount of CSR costs disclosed by the company cannot be used as guarantee for the low aggressive tax actions of the company. The result of the descriptive statistics in Table 4 shows that the average cost incurred by the manufacturing companies in Indonesia related to CSR is $0.12 \%$ of the company's total operating costs. This value can indicate that CSR practices in Indonesia are still low, so the significance on tax avoidance is very small even has no effect at all. Based on this, CSR cannot be used as an indicator of tax avoidance.

\section{The Effect of Tunneling Incentive on Tax avoidance}

Based on the results of statistical tests that have been done in Table 4, it shows that there is a significant effect of tunneling incentive towards Tax avoidance, so that the second hypothesis in this study is accepted. One of forms of tunneling incentive is transfer pricing. According to Eiteman, et al., (2010), determination of transfer pricing is the first most important method in transferring funds out of foreign subsidiaries. Lo, et. al. (2010) stated that many companies use transfer pricing as a strategy to reduce their tax obligations. Research Result of Lo, et al. (2010) also found evidence that there is a shift in income in multinational companies due to changes in tax rates in Canada, Europe and America.

Agencies in agency theory will utilize tunneling incentive to manage their tax burden so as not to reduce agent performance compensation as a result of reduced corporate profits by the tax burden. Performance measurement indicators can be observed from optimal profits, for this reason, efforts to reduce the tax burden as low as possible in a manner that is classified as legal, namely tax avoidance (Mulyani \& Suryarini, 2017). This result is in line with research conducted by Tang (2016) which says that tunneling could be one of the tax avoidance incentives.

Table 3. The Results of Descriptive Statistics

\begin{tabular}{lcrrrr}
\hline \multicolumn{1}{c}{ Variables } & N & \multicolumn{1}{c}{ Minimum } & \multicolumn{1}{c}{ Maximum } & \multicolumn{1}{c}{ Mean } & Standard Deviation \\
\hline Tax Avoidance & 120 & -0.558 & -0.060 & -0.26021 & 0.080581 \\
CSR & 120 & 0.00001 & 0.01316 & 0.00120 & 0.002179 \\
Tunneling Incentive & 120 & 0.00 & 1.00 & 0.5000 & 0.50210 \\
Fiscal Loss Compensation & 120 & 0.00 & 1.00 & 0.2167 & 0.41370 \\
Debt Policy & 120 & 0.150 & 6.646 & 0.90323 & 0.962247 \\
Profitability & 120 & 0.014 & 0.395 & 0.10601 & 0.077150 \\
Firm Size & 120 & 25.785 & 32.190 & 29.08539 & 1.834058 \\
\hline
\end{tabular}

Source : Output Result of IBM SPSS 21, 2018

Table 4. The Result of Hypothesis Test

\begin{tabular}{llcccc}
\hline No & \multicolumn{1}{c}{ Hypothesis } & Coefficient & Sig & $\alpha$ & Results \\
\hline 1. & $\mathrm{H}_{1}$ : CSR has a negative effect on tax avoidance & -2.004 & 0.525 & 0.05 & Rejected \\
2. & $\mathrm{H}_{2}$ : Tunneling Incentive has a positive effect on tax avoidance & 0.038 & 0.008 & 0.05 & Accepted \\
3. & $\mathrm{H}_{3}$ : Fiscal Loss Compensation has a positive effect on tax & 0.044 & 0.004 & 0.05 & Accepted \\
& avoidance & -0.022 & 0.002 & 0.05 & Accepted \\
4. & $\mathrm{H}_{4}$ : Debt Policy has a positive effect on tax avoidance & 0.303 & 0.001 & 0.05 & Accepted \\
5. & $\mathrm{H}_{5}$ : Profitability has a positive effect on tax avoidance. & 0.004 & 0.328 & 0.05 & Rejected \\
6 & $\mathrm{H}_{6}$ : Firm size has a positive effect on tax avoidance & & &
\end{tabular}

Source : Output Result of IBM SPSS 21, 2018 


\section{The Effect of Fiscal Loss Compensation on Tax avoidance}

The results of hypothesis testing that can be seen in Table 4 shows that there is a significant effect of fiscal loss compensation on tax avoidance, so that the third hypothesis in this study is accepted. Regression coefficient of fiscal loss compensation variable shows a positive direction so that fiscal loss compensation has a positive effect on tax avoidance. According to agency theory, the management of the company as agents will take advantage of tax incentives in the form of compensation from fiscal losses in the previous year, because the existence of the compensation will reduce the tax burden and profit after tax in that year will be higher.

Fiscal loss compensation received by the company will reduce the tax burden that must be paid by the company or even the company does not pay taxes at all if the profits obtained by the company in the following year have not been able to cover the company's fiscal losses in the previous year. The company has taken advantage of the loophole in the Law Number 36 of 2008 to minimize the tax burden. Research conducted by Kurniasih \& Sari (2013) which proves that fiscal loss compensation has a significant effect on tax avoidance.

\section{The Effect of Debt Policy on Tax avoidance}

The results of hypothesis testing which can be seen in Table 4 shows that debt policy has a negative effect on tax avoidance. Thus, the fourth hypothesis in this study is accepted. This means that the increase in the debt policy ratio affects on the decline in tax avoidance done by the company. Law Number 36 Year 2008 concerning Income Tax states that loan interest is a cost that can be deducted from taxable income. This means that the company has taken advantage of the loophole in the regulation, namely by choosing debt funding to finance its operational activities so that interest costs arise. Thus, it can be interpreted that companies using debt policy do not need to take tax avoidance measures to produce a minimum tax burden.

(Mutamimah \& Rita, 2009). The results of this study support the trade-off theory revealed by Myers (2001) which states "Companies will owe up to a certain debt level, where the tax savings (tax shields) from additional debt is equal to the cost of financial difficulties (financial distress)". The trade-off theory states that the use of debt by companies can provide benefits in order to obtain tax shield (Mutamimah \& Rita, 2009). The results of this study are in line with research conducted by Noor et al. (2010) and Kurniasih \& Sari (2013).

\section{The Effect of Profitability on Tax avoidance}

The results of hypothesis testing which can be seen in Table 4 shows that profitability has a positive effect on tax avoidance, so the fifth hypothesis in this study is accepted. The increase in profitability ratios will have an impact on increasing tax avoidance by companies. Logically, the higher the value of ROA, means the higher the value of the company's net profit and the higher the profitability. Companies that have high profitability have the opportunity to position themselves in tax planning that reduces the amount of tax liability burden (Chen, et. al., 2010).

Agency theory will spur agents to increase corporate profits. When the profit earned increases, the amount of income tax will increase in accordance with the increase in corporate profits. Agents in agency theory will try to manage their tax burden so as not to reduce agent performance compensation as a result of reduced corporate profits by the tax burden. High profitability means that the company has succeeded in utilizing the benefits of the tax incentives and other tax deductions (Darmadi, 2013). The results of this study are in line with research conducted by Kurniasih \& Sari (2013), and that shows that there is a positive influence between ROA on tax avoidance.

\section{The Effect of Firm Size on Tax avoidance}

The results of hypothesis testing which can be seen in Table 4 show that firm size does not affect on tax avoidance, so the sixth hypothesis of this study is rejected. The size of the company scale is not able to influence the company in conducting tax avoidance. The results of this study are not in line with the theory of political power which states that large companies have large resources so that they can influence the political process according to their wishes including regulating activities in optimal tax savings.

Putri \& Suryarini, (2017) suspected that the resources owned by the company are not used to reduce tax costs but rather to help companies improve corporate performance. When a company has high gross circulation but pays low taxes, it is likely that the tax authorities will suspect it. If this happens, the company will be penalized or fined. Therefore, companies tend to be obedient to taxes.

The results of this study successfully support the research conducted by Rusydi (2013) which shows that firm size does not affect on aggressive tax avoidance. The perception of tax as a burden among business people or the community in general is one indication of the emergence of tax avoidance behaviour in Indonesia. In addition, there is still weak supervision by tax authorities on business people, especially small companies, which causes aggressive tax avoidance behaviour to spread across all sizes of small and large companies (Rusydi, 2013).

\section{CONCLUSIONS}

Based on data analysis and discussion that has been conducted, it can be concluded that only tunneling incentive, fiscal loss compensation, and profitability are able to increase tax avoidance. The results of the study indicate that the variable of firm size using a total sales proxy do not affect on tax avoidance. Future research can use other measures such as total assets and market capitalization as proxy for firm size. 


\section{REFERENCES}

Andreas, H. H., Sucahyo, U. S., \& Elisabeth, D. (2015). Corporate Social Responsibility Dan Profitabilitas. Jurnal Manajemen, 15(1), 119-136.

Anouar, D. (2017). The Determinants of Tax Avoidance within Corporate Groups: Evidence from Moroccan Groups. International Journal of Economics, Finance and Management Sciences, 5(1), 57.

Brian, I., \& Martani, D. (2014). Analisis pengaruh penghindaran pajak dan kepemilikan keluarga terhadap waktu pengumuman laporan keuangan tahunan perusahaan. Simposium Nasional Akuntansi 17 Mataram, Lombok, 16(2), 1-20.

Chen, S., Chen, X., \& Cheng, Q. (2010). Are Family Firms more Tax Aggressive than Non- family Firms? Journal of Financial Economics, 95(1), 41-61.

Darmadi, I. N. H., \& Zulaikha. (2013). Analisis faktor yang mempengaruhi manajemen pajak dengan indikator tarif pajak efektif. Diponegoro Journal of Accounting (Vol. 2).

Darmawan, I. G. H., \& Sukartha, I. M. (2014). Pengaruh Penerapan Corporate Governance, Leverage, ROA dan Ukuran Oerusahaan pada Penghindaran Pajak. EJurnal Akuntansi, 9(1), 143-161.

Eiteman, D. K., A. I. Stonehill, dan M. H. Moffett . (2010). Multinational Business Finance 12th edition. Pearson. (ESM).

Ghozali, I. (2013). Aplikasi Analisis Multivariate dengan Program IBM SPSS 21 Update PLS regresi. (P. P. Harto, Ed.) (Edisi Ketu). Semarang: Badan Penerbit Universitas Diponegoro.

Halioui, K., Neifar, S., \& Abdelaziz, F. Ben. (2016). Corporate governance, CEO compensation and tax aggressiveness : evidence from American firms listed on the NASDAQ 100. Review of Accounting and Finance, 15(4), 445-462.

Hoi, C. K., Wu, Q., \& Zhang, H. (2013). Is corporate social responsibility (CSR) associated with tax avoidance? Evidence from irresponsible CSR activities. Accounting Review, 88(6), 2025-2059.

Hsieh, Y.-C. (2012). New evidence on determinants of corporate effective tax rates. African Journal of Business Management, 6(3), 1177-1180.

Jensen, M. C., \& Meckling, W. H. (1976). Theory of the firm: Managerial behavior, agency costs and ownership structure. Journal of Financial Economics, 3(4), 305-360.

Kiesewetter, D., \& Manthey, J. (2017). Tax avoidance, value creation and CSR - a European perspective. Corporate Governance (Bingley), 17(5), 803-821.

Kurniasih, T., \& Sari, M. M. R. (2013). Pengaruh Return on Assets, Leverage , Corporate Governance , Ukuran Perusahaan Dan Kompensasi Rugi Fiskal Pada Tax Avoidance. Buletin Studi Ekonomi, 18(1), 58-66.

Lanis, R., \& Richardson, G. (2011). Corporate social responsibility and tax aggressiveness: An empirical analysis.
Journal of Accounting and Public Policy, 31(1), 86-108.

Lanis, R., \& Richardson, G. (2015). Is Corporate Social Responsibility Performance Associated with Tax Avoidance? Journal of Business Ethics.

Lo, A. W. Y., Wong, R. M. K., \& Firth, M. (2010). Tax, Financial Reporting, and Tunneling Incentives for Income Shifting: An Empirical Analysis of the Transfer Pricing Behavior of Chinese-Listed Companies. The Journal of the American Taxation Association, 32(2), 1-26.

Mulyani, S., \& Suryarini, T. (2017). Analisis Determinan Tax Avoidance Pada Perusahaan Manufaktur Di Indonesia. Jurnal RAK Riset Akuntansi Keuangan), 2(3), 53-66.

Noor, R. M., Fadzillah, N. S. M., \& Mastuki, N. A. (2010). Corporate Tax Planning: A Study On Corporate Effective Tax Rates of Malaysian Listed Companies. International Journal of Trade, Economics and Finance, 1(2), 189-193.

Putri, T. R. F., \& Suryarini, T. (2017). Factors Affecting Tax Avoidance on Manufacturing Companies Listed on IDX. Accounting Analysis Journal, 6(3), 407-419.

Rodriguez, E., F. And Arias, A., M. 2013. "Do Business Characteristics Determine an Effective Tax Rate?". The Chinese Economy, 45(6), 60-83.

Rusydi, M. K. (2013). Pengaruh Ukuran Perusahaan Terhadap Aggressive Tax Avoidance Di Indonesia. Jurnal Akuntansi Multiparadigma, 4(2), 322-329.

Scott, William R. (2010). "Financial Accounting Theory", Sixth Edition. Pearson Canada Inc. Toronto.

Setyaningrum, C. D., \& Suryarini, T. (2016). Analysis of Corporate Income Tax Reduction A Study Case on Manufacturing Companies in Indonesia in The Year 20082014. Jurnal Dinamika Akuntansi, 8(1), 14-22.

Siregar, R., \& Widyawati, D. (2016). Pengaruh Karakteristik Perusahaan Terhadap Penghindaran Pajak Pada Perusahaan Manufaktur Di Bei. Jurnal Ilmu \& Riset Akuntansi, 5(2).

Siswanti, \& Kiswanto. (2013). Analisis Determinan Tax Aggresiveness pada Perusahaan Multinasional. Accounting Analysis Journal, 1(2), 1-6.

Tang, T. Y. H. (2016). Privatization, tunneling, and tax avoidance in Chinese SOEs. Asian Review of Accounting, 24(3), 274-294.

Turyatini. (2017). The Analysis of Tax Avoidance Determinant on The Property and Real Estate Companies. Jurnal Dinamika Akuntansi, 9(2), 143-153.

.(2008). Undang-Undang Republik Indonesia Nomor 36 Tahun 2008 Tentang Pajak Penghasilan. (2008). Jakarta: Presiden Republik Indonesia.

Wahyudi, D. (2015). Analisis Empiris Pengaruh Aktivitas Corporate Social Responsibility (CSR) terhadap Penghindaran Pajak di Indonesia. Edisi, 2(4), 5-17.

Winarsih, P, \& M. S. Kusufi. (2014). Pengaruh Good Corporate Governance dan Corporate Social Responsibility Terhadap Tindakan Pajak Agresif. Simposium Nasional Akuntansi 17 Mataram, Lombok, 24-27

Yuniasih, N. W., Rasmini, N. K., \& Wirakusuma, M. G. (n.d.). Pengaruh Pajak Dan Tunneling Incentive Pada 